\title{
Indigenous plant foods of Dikgale community in South Africa
}

\author{
Sejabaledi A. Rankoana (1D
}

\begin{abstract}
Indigenous plant materials are sources of staple food for many people in the world. In the African continent, many rural communities continue to collect, grow and consume rain-fed food crops. Consumption of these indigenous food sources could accomplish food security and improved nutrition to prevent hunger, poverty and malnutrition. The present study is an ethnobotanical study conducted to identify, collect and describe the indigenous plant foods used by the members of a rural community in Limpopo Province, South Africa, to fulfil dietary requirements. Ethnobotanical data were collected over 12 months through semi-structured interviews with men and women aged between 32 and 90 years. The study presents 27 indigenous pants belonging to 16 families. Of the species, six are sources of grain, twelve vegetables and eleven fruits. The grains and fewer vegetables and fruits are cultivated in the home gardens. Most of the vegetable and fruit crops grow in the wild, and their procurement is by collecting and gathering. Consumption of the plant materials is limited to their availability, which is determined by favourable environmental conditions. The study results could be used as part of the database for the indigenous resources and practices that the South African Government may consider towards the achievement of the United Nations Sustainable Development Goal 2 to end hunger, achieve food security and improve nutrition and sustainable agriculture. The study suggests that food security could be attained by drawing on the indigenous skills and practices used to fulfil household dietary requirements.
\end{abstract}

Keywords: Sustainable Development Goals, Food security, Plant foods, Rural community, Limpopo Province

\section{Introduction}

The use of indigenous plant materials for food is part of indigenous knowledge and practices developed and accumulated over generations. These systems formed the basis of local-level decision-making in agriculture and food production [1]. Historically, indigenous plants were the sole dietary components for hunter-gatherer and forager cultures [2]. Local communities relied on diversified diet which incorporated edible plant materials cultivated in the home gardens with some edible plant materials collected from the wild consumed in order to cope with food insecurity [3]. In the African continent, for example, more than $95 \%$ of households supplement their diets with wild plant foods such as the roots, leaves

Correspondence: Sejabaledi.rankoana@ul.ac.za

Department of Sociology and Anthropology, University of Limpopo, Private Bag x 1106, Sovenga 0727, South Africa and grass [4]. These communities produce and consume indigenous fruits and vegetables to ensure food selfsufficiency and sustained human populations millions of years ago and still do so today [5]. It is reported that about 300 million people throughout the world gain part or all of their livelihood and food from the forests [6, 7]. Forests or wild plants provide staple food for indigenous people, serve as complementary food for non-indigenous people and offer alternative sources of cash income [8-10].

Indigenous plant foods have always been important in the folk traditions [11]. Many rural community members continue to produce and consume rain-fed cultivated crops and wild plants [12]. Poor households in Zimbabwe rely on wild fruits as alternatives to cultivated food plants for a quarter of all dry season's meals. Similarly, in Northern Nigeria, leafy vegetables and other bush foods are collected as daily supplements to relishes

(c) The Author(s). 2021 Open Access This article is licensed under a Creative Commons Attribution 4.0 International License, which permits use, sharing, adaptation, distribution and reproduction in any medium or format, as long as you give appropriate credit to the original author(s) and the source, provide a link to the Creative Commons licence, and indicate if changes were made. The images or other third party material in this article are included in the article's Creative Commons licence, unless indicated otherwise in a credit line to the material. If material is not included in the article's Creative Commons licence and your intended use is not permitted by statutory regulation or exceeds the permitted use, you will need to obtain permission directly from the copyright holder. To view a copy of this licence, visit http://creativecommons.org/licenses/by/4.0/. 
and soups [11]. In Swaziland, indigenous food plants are still of great importance and contribute a greater share to the annual diet than foods from the retails. In Ethiopia, continued reliance on edible plant species is remarkable in poor families $[13,14]$. Knowledge of indigenous plant foods is evident in the arid areas of Botswana [15]. Edible wild plants proved high nutritional value and play an important role in the prevention of malnutrition in South African rural communities [10]. However, ethnobotanical studies are useful to document indigenous food resources before this essential cultural heritage becomes extinct [10].

Over the last decade, the analysis of microparticles entrapped in dental calculus has contributed significantly to the knowledge about ancient subsistence systems and human interaction with different environments [16]. Evidence on the ancient use of plant species demonstrates the contribution of plants to the human diet, remains difficult to estimate by using dental calculus, due to archaeological matrix's multifactorial aetiology [17, 18]. This is also applicable to Limpopo Province, South Africa, where evidence of the use of plants as foods is still limited despite the fact that these species continue to satisfy the daily dietary requirements of many rural communities. The goal of the present study was to identify, collect and describe the types of indigenous crops grown in the home gardens and those that are collected from the wild, used as sources of food. Identification and collection of the information is essential as their availability is dependent upon favourable climatic conditions. However, the remarkable impacts of climate hazards, namely, drought, depletion of biodiversity, soil erosion and decreased agricultural productivity, may lead to their scarcity and extinction [12]. South Africa's biodiversity of plant foods could potentially be used to identify concepts and products for different markets such as edible plants as sources of new and natural colourants and flavourants, nutritional supplements and for control of hunger [8].

\section{Materials and methods}

\section{Study area}

The study is based on fieldwork conducted in Dikgale community in the Limpopo Province, South Africa. Dikgale community is located within Polokwane Local Municipality approximately $40 \mathrm{~km}$ from Polokwane City, and $15 \mathrm{~km}$ from University of Limpopo in Mankweng Township (Fig. 1). The community covers an area of 71 $\mathrm{km}^{2}$ and is $6-\mathrm{km}$ long and $10.8-\mathrm{km}$ wide. It bounded in the south and southeast by the Strydpoort Mountains and in the east and northeast by the Wolkberg. The area has an annual rainfall of approximately $505 \mathrm{~mm}$. It has a daily average summer temperature of between 16 and $27^{\circ} \mathrm{C}$ and between 5 and $19^{\circ} \mathrm{C}$ in winter. Summer rainfall occurs between October and April, followed by a dry winter season [19]. The natural vegetation consists of grassland and woodlands. Most community members still value cultural traditions such as traditional healing, livestock raising, ploughing the fields and ritual offering which are highly reliant on the production and use of indigenous crops [20]. The rain-fed crops are mostly planted in the home gardens than in the ploughing fields due to intermittent rainfall patterns. Cattle, goats and sheep are raised by fewer households. Livestock raising is no longer common practice because stock feed is sourced from the local white farms due to the scarcity of natural feed from the natural wild [19].

Majority of the community members grow indigenous food crops in the home gardens as their major food to provide additional dietary requirements for a balanced intake. A large amount of biomass is harvested green and cooked for everyday requirements. Many indigenous species have potential as food, medicine and fodder, but they have to be sufficiently abundant as well as accessible to come into everyday use [19].

The community is rural with more than 50 years of existence. It has a population of about 45,083 with a population density of 116 per $\mathrm{km}^{2}$. A large proportion of adult community members are migrant workers, while others work as farm labourers on neighbouring farms or as general workers in the local hospital, clinics and the University of Limpopo. Unemployment rate is higher among the youth [20]. Dwelling units consist of a mixture of traditional mud huts and conventional brick houses. A few households have water taps in their yards, but most community members fetch water from taps situated at strategic points in the community. Most households have pit latrines in their yards, but there is no organised waste disposal. Infrastructure is poor, but the main roads are tarred. Remarkable achievements include building of schools and clinic, and construction of roads linking the community with major resource centres such as the university, hospital and neighbouring communities [20].

\section{Participants}

The study was conducted with a sample of 100 purposively selected community members. The participants, cattle-herders (20), men (31) and women (49), were selected through non-random sampling. The participants were 53 males and 47 females aged between 32 and 97 years. A larger number (40\%) of participants were pensioners, self-employed (34\%) and 5\% were professionals and $21 \%$ general workers. Most of the participants (67\%) belong to the Zionist Churches, 20\% Apostolic and 13\% were Christians belonging to more than five Christian Churches. 


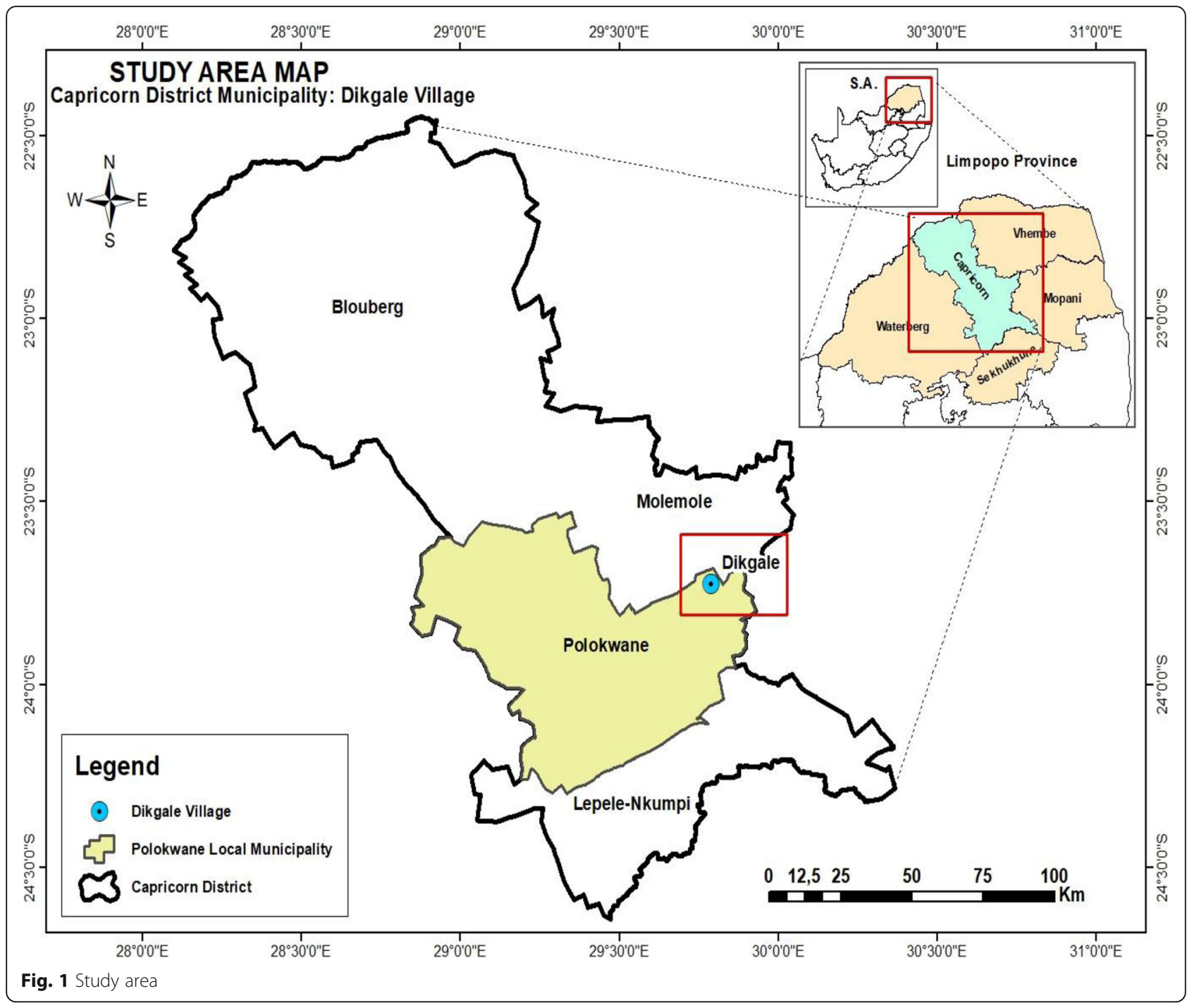

\section{Ethnobotanical survey}

Data were collected through semi-structured interviews to identify, collect and describe the home-grown indigenous crops and wild plant materials used for food. The participants were first asked to name the local names of the crops and edible plant species harvested in the local wild, the parts used and the administration methods, as well as the species habit and availability. The specimens of the indigenous plant species identified by the participants were collected and named from the gardens and the local wild. Collection of specimens was done by collecting smaller quantities of the leaves and fruits under supervision of officials from Limpopo Environmental Management Office. Information about the species local name, plant part used, life form and the use as food was collected at the same time during collection of specimens. The voucher specimens for each of the species' useful parts were collected and numbered in their natural habitat and submitted to the University of
Limpopo Herbarium for identification. The voucher specimens are deposited in the Herbarium. Permission to conduct the study was granted by the local authorities. Consent was obtained from the participants prior to data discussions. The participants signed the consent form as a way of accepting participation in the study. The participants' identities remained confidential, and data were presented without mentioning the names of the participants.

\section{Data analysis}

Data were analysed through a Statistical Package for Social Sciences using frequency counts and percentages. The responses were recorded and compared to establish the names of crops and wild edible plant species and their food uses. The uses of the species were grouped into three categories as grain, vegetable and fruit (Table 1). 


\section{Results and discussion Indigenous plant foods Indigenous plant foods}

The participants identified 27 indigenous plant foods. The plants were identified as crops from the home gardens and plant materials from the wild. The plants were categorised into three groups according to their dietary value to the culture of the participants. The first group was made up of sources of grain followed by sources of vegetables and fruits. These categories are presented in Tables 2, 3 and 4 in alphabetical order by species' families, scientific and vernacular names, description of use and the frequency of identification. The results reported six sources of grain, eleven sources of vegetables and ten sources of fruits. The major life forms were shrubs, herbs and corn (Fig. 2). Shrubs (22\%) grow in the wild and are collected as sources of fruits. Herbs (67\%) mostly grow as weeds in the wild, ploughing fields and home gardens collected as sources of vegetables. Three types of indigenous corn were cultivated in the home gardens as sources of grain, which was either ground into meal or eaten raw as whole grain stews.

The plant uses included grain, vegetables and fruits. Many of the plants had more than one uses (Table 2). For example, three species in the Cucurbitaceae family were identified as sources of vegetables and fruits. The leaves were sources of vegetables. Mature plants bore edible fruits.

\section{Cultivated plant foods}

Of the 27 indigenous food plants identified and collected during the study, all sources of grain (6 crops) were cultivated in the home gardens during the rainy season. The crops were grown in the home gardens to provide grain as a basic source of meal used to prepare the hard porridge. The remaining three crops were sources of grain consumed as side dish and whole grain stews. The three crops in the Fabaceae family are also grown in the home gardens. The first was Vigna sinensis sp., which was identified as a source of vegetable and its fruits are relished as side dish and whole grain stew. The other two crops within the family bear fruits, which are prepared as side dish or whole grain stew. Four crops in the Cucurbitaceae family were also identified as some of the crops grown in the home gardens. These crops were grown with other crops in the same garden as sources of vegetables and fruits. Upon maturity, the crops bear

Table 1 Categories of plant foods

\begin{tabular}{llll}
\hline Category & Vegetables & Fruits & Grain \\
\hline Cultivated & 4 & 4 & 6 \\
Wild & 7 & 6 & 0 \\
Total & 11 & 10 & 6 \\
\hline
\end{tabular}

fruits, which are eaten raw or used to prepare a vegetable porridge.

\section{Wild plant foods}

Cucumis africanus sp. is the only vegetable source within the Cucurbitaceae family, which is not cultivated. Like other six sources of vegetables, the crops grow in the wild after the first rain. These plants were distinguished from the non-edible plant materials in the wild by participants. Five other sources of fruits were also identified as non-cultivated.

\section{Seasonal availability}

The fruits from the wild were seasonal and available between the months of November and April. The fruits from the home gardens were readily available for consumption from April to June. The wild vegetables were available at the same time with the home-grown types as from September throughout to March. Grain crops were produced in the home gardens and fields after the first rain between October and December and are harvested and consumed between February and May. Seasonal availability of crops identified in the study is further supported by observations that most of the wild edible plant species are only available during the rainy season [15].

\section{Grain sources}

Grain obtained from mature Sorghum sp., Pennisetum sp. and Zea mays was identified as sources of a meal used to prepare hard porridge, which is the staple food of the community. The meal was obtained by grinding the grain on grinding stones or ponding the grain by mortar and pestle to produce a meal which could last for a year. Vigna sinensis sp. was identified a valued crop and a source of relish and snack. Voandzeia sp. bears round tubers which were taken as an in-between meal and relish. The vegetables and grains relish hard porridge. This discernment is supported by the observations that in the semi-arid communities of Kenya, grain crops are continued to be consumed to fulfil household daily dietary requirements [21].

\section{Vegetable sources}

Of the species identified, eleven were sources of vegetables. These vegetables were harvested and used directly without any form of trade. The fresh tender leaves were collected, washed, seasoned with salt and boiled to make the most delicious and popular indigenous vegetables. The uncooked leaves and surplus from the cooked materials were dehydrated and preserved for future use. Very often Elephantorrhiza elephantina (Burch.) Skeels and Amaranthus sp. were cooked with Cleome monophylla L. and Cucumis africanus L.f. to stabilise their mild bitter taste. These herbs were the largest group of species 
Table 2 Grain sources

\begin{tabular}{|c|c|c|c|c|c|c|}
\hline \multirow[t]{2}{*}{$\begin{array}{l}\text { Family } \\
\text { name }\end{array}$} & \multirow[t]{2}{*}{$\begin{array}{l}\text { Scientific name and voucher } \\
\text { numbers }\end{array}$} & \multirow[t]{2}{*}{$\begin{array}{l}\text { Common } \\
\text { name }\end{array}$} & \multirow[t]{2}{*}{$\begin{array}{l}\text { Vernacular } \\
\text { name }\end{array}$} & \multirow[t]{2}{*}{ Description of use } & \multicolumn{2}{|c|}{$\begin{array}{l}\text { Frequency of } \\
\text { identification }\end{array}$} \\
\hline & & & & & Male & Female \\
\hline \multirow[t]{3}{*}{ Poaceae } & Andropogon sorghum (L.) Brot. & Sorghum & Lebelethoro & $\begin{array}{l}\text { Matured heads are harvested, threshed and grounded } \\
\text { to make fine meal used to prepare porridge }\end{array}$ & 53 & 47 \\
\hline & Pennisetum spicatum Koern \& vars. & Kaffir-millet & Leotsa & $\begin{array}{l}\text { Matured heads are harvested, threshed and grounded } \\
\text { to make fine meal used to prepare porridge }\end{array}$ & 53 & 47 \\
\hline & Zea mays L. & Maize & Lefela & $\begin{array}{l}\text { Fresh cobs are boiled or grilled to make a snack. } \\
\text { Dried cobs are harvested, threshed and grounded to } \\
\text { make fine meal used to prepare porridge }\end{array}$ & 53 & 47 \\
\hline \multirow[t]{3}{*}{ Fabaceae } & Vigna sinensis (L.) Endb. & Cow pea & Monawa & $\begin{array}{l}\text { Fresh leaves are boiled to make relish. The pods are } \\
\text { boiled and eaten as snack. Dried beans are harvested, } \\
\text { threshed and prepared as side-dish or whole-grain stew }\end{array}$ & 42 & 47 \\
\hline & Vigna subterranean (L.) Verdc. & Njugo bean & Tloo-marapo & $\begin{array}{l}\text { Fresh underground tubers are harvested, boiled and } \\
\text { eaten raw. Dried beans are harvested, threshed and } \\
\text { prepared as relish or whole-grain stew }\end{array}$ & 53 & 47 \\
\hline & Phaseolus aureus L. & Mung bean & Lehlodi & $\begin{array}{l}\text { Dried beans are harvested, threshed and prepared to } \\
\text { make side-dish or whole-grain stew }\end{array}$ & 22 & 47 \\
\hline
\end{tabular}

consumed in Bulgaria with above-ground parts; young leaves, shoots and stems are gathered and used as vegetables [22]. The use of wild edible herbs is widespread in South African rural communities, with over $90 \%$ of households using them in a single community [10]. In South Africa, poor households tend to rely on indigenous leafy vegetables more than their counterparts because they lack the financial means to purchase vegetables in the markets [12]. Surplus vegetables are always stored for future consumption during the period of food scarcity $[23,24]$.

\section{Fruit sources}

The participants reported that the fruits are consumed as snacks. The fruits were consumed fresh. This type of consumption is different from the consumption of indigenous fruits in Bulgaria which are consumed fresh, dried or after thermal or lacto-fermented processing [22]. Sclerocarya birrea fruits were eaten after peeling off the skins. The white, fleshy parts surrounding the kernels are sucked off and had a pleasant sour-sweet taste. Dry kernels were collected in large quantities after the preparation of marula beer and were stored until

Table 3 Vegetable sources

\begin{tabular}{|c|c|c|c|c|c|c|}
\hline \multirow[t]{2}{*}{ Family names } & \multirow[t]{2}{*}{ Scientific name } & \multirow[t]{2}{*}{ Common name } & \multirow[t]{2}{*}{$\begin{array}{l}\text { Vernacular } \\
\text { name }\end{array}$} & \multirow[t]{2}{*}{ Description of use } & \multicolumn{2}{|c|}{$\begin{array}{l}\text { Frequency of } \\
\text { identification }\end{array}$} \\
\hline & & & & & Male & Female \\
\hline \multirow[t]{2}{*}{ Amaranthaceae } & Amaranthus thunbergii Moq. & Pigweed & Theepe & $\begin{array}{l}\text { Fresh, tender leaves are boiled to make a } \\
\text { palatable side-dish. Dried leaves or cooked } \\
\text { side-dish can be dried for future use }\end{array}$ & 53 & 47 \\
\hline & Amaranthus spinosus (L.) & Thorny pigweed & Letelele & Fresh leaves are boiled to make slimy relish & 12 & 47 \\
\hline Asteraceae & Vernonia fastigiata. Oliv. \& Hiern & Langbeen bossie & Lehlanye & $\begin{array}{l}\text { Tender leaves are boiled to make bitter-taste } \\
\text { vegetable }\end{array}$ & 19 & 47 \\
\hline Capparidaceae & Cleome monophylla L. & Spider whips & Lerotho & $\begin{array}{l}\text { Young leaves and flowers are boiled to make } \\
\text { relish which can be stored for future use }\end{array}$ & 53 & 47 \\
\hline \multirow[t]{5}{*}{ Cucurbitaceae } & Citrullus vulgaris Schrad & Kaffir melon & Morotse & $\begin{array}{l}\text { Tender leaves and immature fruit are boiled } \\
\text { to make relish }\end{array}$ & 53 & 47 \\
\hline & Citrullus vulgaris Schrad. Vars. & Watermelon & Mogapu & Well-cooked tender leaves make palatable relish & 22 & 47 \\
\hline & Cucurbita pepo. L. & Pumpkin & Mofodi & Immature leaves, fruits and flowers make relish & 53 & 47 \\
\hline & Cucumis africanus L.f. & Wild cucumber & Monyaku & Tender leaves make relish & 53 & 47 \\
\hline & Lagenaria vulgaris Ser. & Gourd & Moraka & Immature leaves and fruits make relish & 16 & 47 \\
\hline Fabaceae & $\begin{array}{l}\text { Elephantorrhiza elephantina } \\
\text { (Burch.) Skeels }\end{array}$ & Eland's wattle & Mošitsana & Young, tender leaves make a relish & 14 & 47 \\
\hline Zygophyllaceae & Tribulus terrestris L. & Devil's thorn & Tshehlo & Fresh leaves make a relish & 8 & 47 \\
\hline
\end{tabular}


Table 4 Fruit sources

\begin{tabular}{|c|c|c|c|c|c|c|}
\hline \multirow[t]{2}{*}{ Family name } & \multirow[t]{2}{*}{ Scientific name } & \multirow{2}{*}{$\begin{array}{l}\text { Common } \\
\text { name }\end{array}$} & \multirow{2}{*}{$\begin{array}{l}\text { Vernacular } \\
\text { name }\end{array}$} & \multirow{2}{*}{$\begin{array}{l}\text { Description of } \\
\text { use }\end{array}$} & \multicolumn{2}{|c|}{ Frequency of identification } \\
\hline & & & & & Male & Female \\
\hline Anacardiaceae & Sclerocarya birrea (A. Rich) Hochst. & Marula & Morula & Fruit taken as snack & 53 & 47 \\
\hline Aquifoliaceae & Ilex mitis (L.) Radlk. & Cape holly & Monamane & Fruit taken as snack & 53 & 47 \\
\hline Cactaceae & Opuntia megacantha Salm Dyck & Prickly pear & Motoro/foeya & Fruit taken as snack & 53 & 47 \\
\hline \multirow[t]{3}{*}{ Cucurbitaceae } & Citrullus vulgaris Schrad Ex. E and Z. & Kaffir melon & Morotse & $\begin{array}{l}\text { Fruit used to make } \\
\text { vegetable porridge }\end{array}$ & 53 & 47 \\
\hline & Cucurbita pepo. L. & Pumpkin & Mofodi & $\begin{array}{l}\text { Fruit used to make } \\
\text { vegetable porridge }\end{array}$ & 53 & 47 \\
\hline & Citrullus vulgaris Schrad. Vars. & Watermelon & Mogapu & Fruit taken as snack & 53 & 47 \\
\hline Poaceae & Sorghum vulgare Pers. & Sweet reed & Ntsho & Fruit taken as snack & 53 & 47 \\
\hline Olacaceae & Ximenia caffra Sond. & Sour plum & Motšhidi & Fruit taken as snack & 53 & 47 \\
\hline Rubiaceae & Vangueria infausta. Burch. & Wild medlar & Mmilo & Fruit taken as snack & 53 & 47 \\
\hline Sapotaceae & Chrysophyllum magalismontanum Sond. & Wild plum & Mohlatswa & Fruit taken as snack & 53 & 47 \\
\hline
\end{tabular}

needed. The embryos obtained after cracking the kernels were important sources of oil. Oil was obtained by pounding large quantities of embryos with mortar and pestle; after which, the dough was squeezed to extract the oil. In the past, this oil was used to cook venison. The embryos were sometimes added to whole grain stews to improve flavour. Ximenia caffra fruits were relished for their refreshing sour taste. Vangueria infausta fruits were relished for their pleasant, soursweet taste while Ilex mitis was enjoyed for its faintly sweetish rather bitter taste.

\section{Knowledge of the use of indigenous plant foods}

Knowledge of wild edible plant species was unequally distributed among participants (Table 5). The women of all age groups identified the sources of grain, fruits and vegetables. Men identified the fruit plants and have little

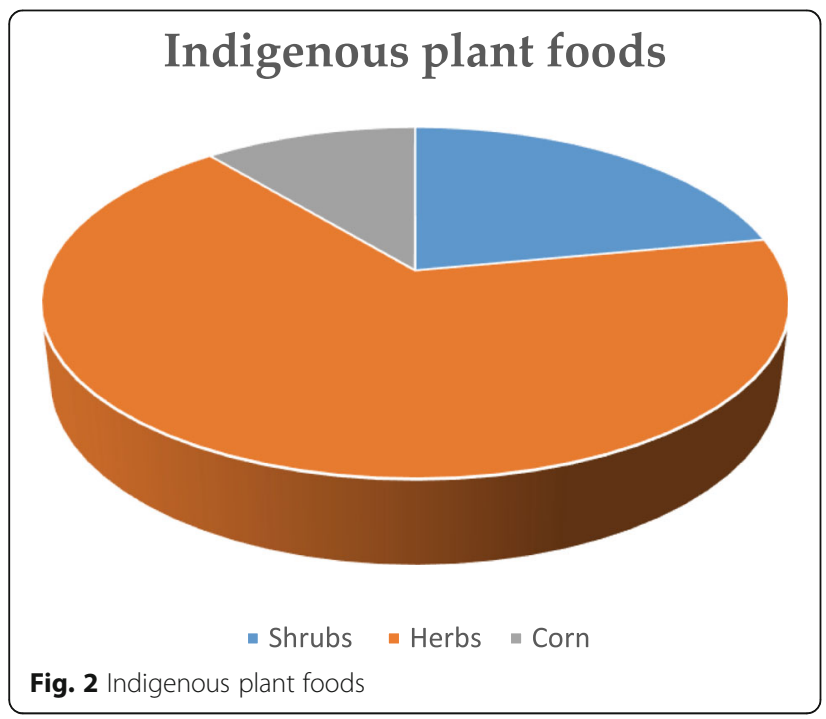

knowledge of vegetable sources. This type of knowledge distribution is directly related to the cultural responsibilities assigned to or performed by men and women in the community [12]. This shows that the women were knowledgeable about plant species that were cooked for household consumption, while the men were knowledgeable about those that were eaten as snacks. Among South African rural communities depending on wild plant food for survival, knowledge of leafy vegetables is within the domain of the women only, and knowledge of fruit and cereals is mainly in the male domain $[25,26]$. Another important activity in the acquisition and maintenance of knowledge about edible plants is herding. When following cattle or sheep, children and adult herders have much time to observe nature as they move through the landscape $[27,28]$. The women are the main knowledge holders and custodians of the major activities of community life such as agriculture, health care, food security and indigenous natural resources $[29,30]$.

\section{Conclusion}

The study goal was identification, collection and description of the crops grown in the home gardens and indigenous plants collected from the wild, which are sources of food to the study community. A non-random sample was used to identify, collect and describe the indigenous

Table 5 Knowledge of wild edible plant species

\begin{tabular}{ll}
\hline Participants & Number of edible plants identified \\
\hline Cattle herders & Fruits from the wild \\
Men & $\begin{array}{l}6 \text { fruits from the wild, } 5 \text { fruits from the home-garden } \\
\text { Women }\end{array}$ \\
$\begin{array}{l}\text { All vegetable sources, } 3 \text { fruits from the wild, and } 5 \\
\text { fruit sources from the home garden }\end{array}$ \\
\hline
\end{tabular}


food plants among cattle herders and adults in the community. The results show continued dependency on subsistence farming of three types of corn, and five sources of vegetables and fruits in the home gardens to provide household food requirements. Six naturally occurring plant materials were known and collected for their nutritional value as sources of vegetables and another six as sources of fruits. The cultivated sources of vegetables are also source of fruits when they reach maturity. Participants have developed the knowledge of the seasons during the plant materials are ready for collection and consumption. Knowledge of the indigenous plant use held by the participants is related to the cultural obligations assigned to men and women in the community. However, the fruits were identified mostly by the men and herders whose part of cultural obligations is to tend livestock by driving it to the wild for grazing. The women's knowledge of sources of vegetables and grain fulfils their obligation as household food providers. The study results could be used as part of the database for the indigenous resources and practices that the South African Government may consider towards the achievement of the United Nations Sustainable Development $\mathrm{Goal}_{2}$ to end hunger, achieve food security and improve nutrition and sustainable agriculture. The study suggests that food security could be attained by drawing on the indigenous skills and practices used to fulfil household dietary requirements.

\section{Acknowledgements}

To the participants for their kindness and interest in taking part in the study.

\section{Informed consent}

Participants consented to take part in the study by signing the consent form.

\section{Author's contributions}

I am the sole author. The author read and approved the final manuscript.

\section{Availability of data and materials}

Not applicable

\section{Declarations}

\section{Competing interest}

The author declares that she has no competing interests.

Received: 23 March 2021 Accepted: 6 May 2021

Published online: 24 May 2021

\section{References}

1. Warren DM, Brokensha D, Slikkerveer $L J$, editors. The cultural dimension of development: indigenous knowledge systems. London: Intermediate Technology Publications; 1995. https://doi.org/10.3362/9781780444734

2. Bharucha Z, Pretty J. The roles and values of wild foods in agricultural systems. Phil Trans R Soc B. 2010; 365: 2913-2926 doi:https://doi.org/10.1 098/rstb.2010.0123. Accessed Mar 2020, 1554.

3. Webb P, von Braun J. Famine and food security in Ethiopia. Lessons for Africa. Wiley: England; 1994.

4. Guinand Y. Dechassa Lemessa. Wild-food plants in Southern Ethiopia: reflections on the role of 'Famine-Foods' at a time of drought. Addis Ababa: UN-Emergencies Unit for Ethiopia; 2000.
5. USAID. The potential of indigenous wild foods. Workshop Proceedings, 2226 January 2001

6. Pimentel D, McNair M, Buck, L, Pimentel M, Kamil J. The value of forests to world food security. Hum Ecol, 1997; 25,1: 91-120.

7. Teklehaymanot T, Giday M. Ethnobotanical study of wild edible plants of Kara and Kwego semi-pastoralist people in Lower Omo River Valley, Debub Omo Zone, SNNPR Ethiopia. J Ethnobiol Ethnomed. 2010;6(23):1-10. https://doi.org/10.1186/1746-4269-6-23 PMID: 20712910; PMCID: PMC2933608. Accessed 23 Mar 2021.

8. Senbeta F, Gole TW, Denich M, Kellbessa M. Diversity of useful plants in the coffee forests of Ethiopia. Ethnobot Rese Appl. 2013;11:049-69.

9. Bruschi P, Mancini M, Mattioli E, Morganti M, Signorini MA. Traditional uses of plants in a rural community of Mozambique and possible links with Miombo degradation and harvesting sustainability. J Ethnobiol Ethnomed. 2014:10(59):1-22.

10. Shackleton SE, Dzerefos CM, Shackleton CM, Mathabela F. Use and trading of wild edible herbs in the central Lowveld savanna region, South Africa. Economic Bot. 1998:251-9.

11. Hoffman M. Human impacts on vegetation. In: Cowling RM, Richardson DM, Pierce SM, editors. Vegetation of Southern Africa. Cambridge: Cambridge University Press; 1997.

12. Maponya P, Mpandeli S. Climate change and agricultural production in South Africa: impacts and adaptation options. J Agric Scie. 2012:4(10):48-60.

13. Ojelel $\mathrm{S}$, Kakudidi EK. Wild edible plant species utilized by a subsistence farming community in Obalanga sub-county, Amuria district, Uganda. J Ethnobiol Ethnomed. 2015;11(7):1-8. https://doi.org/10.1186/1746-4269-11-7 Accessed 21 Mar 2021

14. Cruz MP, Peroni N, Albuquerque UP. Knowledge, use and management of native wild edible plants from a seasonal dry forest (NE, Brazil). J Ethnobiol Ethnomed. 2013:9(79):1-10.

15. Addis $G$, Urga K, Dikasso D. Ethnobotanical study of edible wild plants in some selected districts of Ethiopia. Hum Ecol. 2005;33:1. https://doi.org/10.1 007/s10745-005-1656-0 Accessed 12 Feb 2021.

16. Cristiani E, Radini A, Edinborough M, Borić D. Dental calculus reveals Mesolithic foragers in the Balkans consumed domesticated plant foods. Proc Natl Acad Sci. 2016;113:10298-303, 37. https://doi.org/10.1073/pnas.1 603477113.

17. Leonard C, Vashro L, O'Connell JF, Henry AG. Plant microremains in dental calculus as a record of plant consumption: a test with Twe foragerhorticulturalists. J Archaeol Sci Rep. 2015;2:449-57. https://doi.org/10.1016/j. jasrep.2015.03.009

18. Gismondi A, D'Agostino A, Di Marco G, Martínez-Labarga C, Leonini V Rickards $\mathrm{O}$, et al. Back to the roots: dental calculus analysis of the first documented case of coeliac disease. Archaeol Anthropol Sci. 2020;12:1-10.

19. Pitso FS, Lebese MR. Traditional use of wild edible plants in arid areas of South Africa. J Hum Ecol. 2014;48(1):23-31.

20. Faber M, Oelofse A, Van Jaarsveld PJ, Wenhold FAM, Jansen van Rensburg WS. African leafy vegetables consumed by households in the Limpopo and KwaZulu-Natal provinces in South Africa. SA J Clin Nutri. 2010;23(1):30-8.

21. Dlamini NR, Moroka T, Mlotshwa L, Reddy J, Botha G. Indigenous edible plants as sources of nutrients and health benefiting components (nutraceuticals). Science Real and Relevance Conference, 2010. Centre for Scientific and Industrial Research (CSIR). 2010.

22. Polokwane Local Municipality Integrated Development Plan (IDP) 2013/ 2014. Limpopo Province, South Africa. Available at: www.limpopo government.gov.za. Accessed 23 Feb 2020.

23. Kanjala C, Alberts M, Byass P, Burger S. Spatial and temporal clustering of mortality in Digkale HDSS in rural northern South Africa. Global Health Action. 2010;3:1-25.

24. Shumsky SA, Hickey GM, Pelletier B, Johns T. Understanding the contribution of wild edible plants to rural social-ecological resilience in semi-arid Kenya. Ecol Soc. 2014;4(34):1-24.

25. Nedelcheva A. An ethnobotanical study of wild edible plants in Bulgaria. Eurasia J Biosci. 2013;7:77-94. https://doi.org/10.5053/ejobios.2013.7.0.10 Accessed 21 Mar 2020.

26. Maanda MQ, Bhat RB. Wild vegetables in the Venda region of Limpopo Province. Int J Experi Botan. 2010:79:189-94.

27. Kwenin WKJ, Wolli M, Dzomeku BM. Assessing the nutritional value of some African indigenous green leafy vegetables in Ghana. J Ani Plant Sci. 2011; 10(2):1300-5. 
28. Jansen Van Rensberg WSJ, Van Averbeke W, Slabber R, Faber M, Van Jaarsveld P, Van Heerden I, WEnhold F, Oelofse A. African leafy vegetables in South Africa. Water South Africa. 2007; 3:317-26. Online at http://www.wrc. org.za. Accessed 16 Mar 2021

29. Hart TGB, Voster HJ. Indigenous knowledge on the South African landscape - potentials for agricultural development. Urban, Rural and Economic

Development Programme. Occasional Paper No 1. Cape Town: Human Sciences Research Council Press; 2006.

30. Łuczaj Ł. Archival data on wild food plants used in Poland in 1948. J

Ethnobiol Ethnomed. 2008; (4):1-12. https://doi.org/10.1186/1746-4269-4-4 Accessed 22 Mar 2020

\section{Publisher's Note}

Springer Nature remains neutral with regard to jurisdictional claims in published maps and institutional affiliations.

Ready to submit your research? Choose BMC and benefit from:

- fast, convenient online submission

- thorough peer review by experienced researchers in your field

- rapid publication on acceptance

- support for research data, including large and complex data types

- gold Open Access which fosters wider collaboration and increased citations

- maximum visibility for your research: over $100 \mathrm{M}$ website views per year

At BMC, research is always in progress.

Learn more biomedcentral.com/submissions 